\title{
Teacher-author-students' polylogue as part of curricular and extracurricular activities dedicated to modern children and teenage literature
}

\author{
Natalya V.Kuteinikova ${ }^{1, *}$ \\ ${ }^{1}$ MIOE, Department of Philological Education, 119034, Moscow, Russia
}

\begin{abstract}
Possible ways and forms of attaching of children and teenagers to reading on the basis of acquaintance and study at school of modern children and teenage literature are examined in the paper; the leading role of teachers of philology is underlined in the process of forming of reader culture of rising generation. On the example of studying of work of S. Vostokova "Frosya Korovina" working methods with the text on the principle "a polylogue "a teacher - an author students"
\end{abstract}

The problem of promoting interest in reading among the younger generations is widely discussed today in the media, the Internet, in many families and even in the government; moreover, the management of schoolchildren's reading habits, as well as the content, meaning, results, effects and barriers inherent to their reading are being examined extensively and productively by researchers from various fields. The studies conducted by psychologists, educators, educational methodologists, librarians and writers generate practical results: projects are being developed, programs are being offered, books are being published [1, 424]; however, science is not always able to keep up with life, and we do not always implement the approaches offered by science in our everyday practice. Moreover, we often reject what is offered by life in many-sided manifestations, including the new books created for children and teenagers of a new century taking into account their interests, preferences and age problems.

But the modern world is, in fact, diverse enough to offer a multitude of forms of introducing children and teenagers to reading, as well as an abundance of ways to initiate them into various reading strategies. The most appropriate term to be used here is perhaps "promoting interest in reading among fifth- to ninth- graders", rather than the more typical for Russian educational methodology "management of students' reading habits." Formation of interest in something assumes various approaches as to motivation on an action, in this case reading both processes and reading both activities [2], and the accounting of specifics of this or that audience, the age / territorial / social group having the preferences. Moreover, at a formation of interest, it is frequent still unstable, various approaches, methods and working methods with literature which anyway are the hidden management of reading pupils of a class or school are assumed. There is nevertheless no set "end goal" like having all students in a group read every book on a certain list, since each student should possess his own unique reading range reflecting his reading level, interests, and preferences; still, it should include 'basic' works taken from "Independent reading lists for fifth- to tenth- graders", and from the reading range typical for children of the same age and interests. Therefore, by introducing several works of modern children's and young adult literature to "Independent reading lists for fifth- to tenth-graders", and analyzing some of them during in-class activities dedicated to extracurricular reading, and at various elective courses, optional programs and hobby clubs, we can partially solve the reading problems of the 21 st century.

Obviously, all children love being read to. That is why, in our opinion, one of the relevant and efficient methods of giving the schoolchildren an incentive to engage in reading as a process and as an activity today is to set up the first-time reading of a given literary work or excerpts thereof in class or as part of an elective course/a hobby club session. This technique is the most efficient in grades 5 to 7 where, after a teacher reads the work to students, a discussion can be started to both identify the first impression made by what students have just heard, and determine exactly how interested they are in content. Here the main thing is to choose a work of art available to perception of children of this age and this collective, with modern problems and realities, easily audible.

Aesthetic perception is always based on and has in its "foundations" reader's personal emotional stance towards the work of art in question. The activity to emotionally deepen the initial impression made by a work can be done by encouraging students to use their imagination, thus inspiring adolescent readers to empathize with the protagonists. For this reason, during the conversation following the recital of one or two excerpts of the work, it is imperative to instigate 
students' imagination, for instance, this can be done while studying the novel Frosya Korovina by Stanislav Vostokov [3] with fifth- or sixth-graders. Specifically, in this case, it is sufficient to read the beginning of the novel in order to make students to read the whole book themselves and discuss it in class.

After the question "What are the main character like?" you can move to a verbal painting as the technique of forming creative imagination of students: you will need to understand how "real Russian woman" Frosya lives with his grandmother in his "historical monument" — "a Residential house of a wealthy peasant Fedor Korovin. The beginning of the XIX century."

Once this house ... was stolen. When the girl has gone to the city to visit the grandmother in the hospital, employees of the Museum of wooden architecture, considering that home "neutral", sorted it and took away to the reserve. The little Frosya and her friends had to give chase in order to bring the house back before Grandma leaves the hospital and comes home. It is virtually impossible to read about the friends' adventures without laughing: this is the real children's comedy; the book manages to vividly depict how children view the adult world of laws and taboos that are sometimes absurd.

Frosya's cherished dream is to become a real peasant woman (despite the fact that her parents are geologists) so that she could never leave her native land. Frosya is happy to perform all the household chores to keep the house "alive", and she helps her grandmother in the garden garden. By examining Frosya's view of the world around her and her attitude towards simple peasant labor, the young readers can embrace the poetry of a childhood spent in the country. This childhood is depicted realistically for the most part, save for a few details - the heroine has a trained Chicken (this her proper name) with whom the girl rides a bicycle to school that in the neighboring village, and a bear Gerasim who has come from a forest area to defend temporarily deserted Frosya from her uncle, the forester.

The young protagonists of Stanislav Vostokov's novel are independent and hard-working; they make their own decisions, they are not afraid of anything, and they are ready to act responsibly in difficult situations. They are already prepared for adulthood, but they are still children, adventure-loving, and full of imagination. More important, though, is the fact that those children think and talk like the modern kids, they are convincing and recognizable, which is why they captivate the minds of young readers. This similarity can serve to set up some comparison-based creative activity (students pick up one subject depending on whether they have previously read the works by Irina Krayeva [4] or Maria Boteva [5]):

- "What are the similarities between the protagonists of Ice Cream Cones by Maria Boteva and Frosya Korovina by Stanislav Vostokov?"

- "How similar are the teenage girls from And Skip Away Outside by Irina Krayeva and A School on a Matchstick by Maria Boteva?"

— "Which protagonists of the books you have read have similar personalities or outlook?"
If Frosya Korovina is studied by fifth- or sixthgraders, the material should be brought to life by staging an exhibition of illustrations in class, or by creating a cooperative electronic slide-show presentation to promote the novel beyond the given school group. In grades 6 and 7, a meta level can be reached by assigning the students with finding some information on museums and conservation areas of wooden architecture, and picking up photos of temples, as well as houses of "richer peasants". Students can either present their project verbally while demonstrating the visual material they've picked, or create a slide-show presentation or a book trailer. As part of this exercise, two or three students are allowed to choose a project topic from a selection beforehand, and projects are later presented in class by children either during or after reading the novel. The range of topics can be as follows:

- "The Vologda Musem of wooden architecture" ('The museum described in Frosya Korovina by Stanislav Vostokov);

_-"The Open-Air Museum of Malye Korely, Region of Arkhangelsk";

— "The Museum of wooden architecture and peasant life. The Vladimir-Suzdal Museum and Reserve";

- "The Kolomenskoye wooden architecture museum, Moscow";

— "Wooden architecture of Russia", etc.

It is high time for the school teachers' community to understand and accept the fact that the direction of educational activities within the school itself has changed. We are convinced that the adolescence is the period when students should discover their personality through reading and understanding fiction, rather than through simply being familiarized with such texts or, at best, listening to the teacher read "the best works of Russian and foreign literature" and "analyzing them by understanding the figurative nature of the literary art based on the principles of the unity of artistic form and content" [6]. In order to elevate oneself to the level of understanding required for the works of art that are actually the best, one needs first to find himself as an individual, as a reader, to grasp the fact that there can be diverse paths in history and in life, but you can always choose which one to follow. In other words, any reader must primarily read, feel and understand literary works that are accessible to his or her age and correspond to his or her reading experience.

\section{References}

1. E.O Galitskikh, Chtenie kak iskusstvo: germenevticheskii aspekt: (Raduga-PRESS, Kirov, 2013) [In Rus]

2. Y.P. Melentyeva, Chtenie: yavlenie, protsess, deyatel'nost' (Nauka, Moskva, 2010) [In Rus]

3. S.Vostokov. Frosya Korovina (Klever-Media-Grupp, Moskva, 2014) [In Rus]

4. I.Krayeva, Baba Yaga pishet (Limbus Press, SPb, 2014) [In Rus]

5. M Boteva, Morozhenoe v vafel'nykh stakanchikakh (KompasGid, Moskva, 2013) 
6. Primernye programmy po uchebnym predmetam. Literatura. 5-9 klassy. Availablt online: URL http://standart.edu.ru/catalog.aspx?CatalogId=2627 (accessed on 24.10.2015) [In Rus] 